\title{
Optimization of oxygen transfer through membrane diffusers for the biological sweetening of biogas
}

\begin{tabular}{|r|l|}
\hline Journal: & Chemical Engineering \& Technology \\
\hline Manuscript ID: & ceat.201200603.R1 \\
\hline Wiley - Manuscript type: & Research Article \\
\hline Date Submitted by the Author: & n/a \\
\hline Complete List of Authors: & $\begin{array}{l}\text { Rodriguez, Ginesta; Universitat Politécnica de Catalunya, Mining } \\
\text { Engineering and Natural Resources } \\
\text { Dorado, Antonio; Universitat Politécnica de Catalunya, Mining Engineering } \\
\text { and Natural Resources } \\
\text { Bonsfills, Anna; Universitat Politécnica de Catalunya, Mining Engineering } \\
\text { and Natural Resources } \\
\text { Gabriel, David; Universitat Autónoma de Barcelona, Chemical Engineering } \\
\text { Gamisans, Xavier; Universitat Politecnica de Catalunya, Mining Engineering } \\
\text { and Natural Resources }\end{array}$ \\
\hline Keywords: & \begin{tabular}{l} 
Bioreactors, Gas-Liquid systems, Mass transfer, Process optimization \\
\hline
\end{tabular} \\
\hline
\end{tabular}

\section{SCHOLARONE ${ }^{\text {m }}$}

Manuscripts 
Optimization of oxygen transfer through membrane diffusers for the biological sweetening of biogas

Ginesta Rodriguez ${ }^{1}$, Antonio D. Dorado ${ }^{1}$, Anna Bonsfills ${ }^{1}$, David Gabriel ${ }^{2}$ and Xavier Gamisans ${ }^{1}$

1 Department of Mining Engineering and Natural Resources. Universitat Politécnica de Catalunya, Spain

${ }^{2}$ Department of Chemical Engineering. Universitat Autónoma de Barcelona, Spain

\begin{abstract}
Biological techniques for the removal of gaseous pollutants such as hydrogen sulfide have proved to be effective, environmentally friendly and economically viable. However, when high concentrations of hydrogen sulfide are treated the process is severely restricted by the oxygen deficit in the liquid phase. Thus, when the oxygen concentration is below the stoichiometric requirement, elemental sulfur is formed and accumulates in the packing material, increasing operating costs and, in extreme cases, requiring the bioreactor to be shut down. In this study the oxygen transfer efficiency provided by a membrane diffuser is evaluated under typical pressure and salinity conditions used for the biological treatment of hydrogen sulfide in biogas. The aim was to determine the optimal operating parameters for enhanced oxygen transfer. The addition of pure oxygen with a membrane diffuser to increase the oxygen transfer rate and the use of a non-aqueous phase to improve oxygen transfer in a bioscrubber system are also evaluated.
\end{abstract}

Key-words: oxygen transfer, biofiltration, membrane diffuser, non-aqueous phase, pressure

\footnotetext{
1 Escola Politécnica Superior d'Enginyeria de Manresa, Universitat Politécnica de Catalunya. Bases de Manresa, 61-73. 08242-Manresa (Spain).

1 Escola Técnica Superior d'Enginyeria, Universitat Autónoma de Barcelona. Edifici C, 08193 Bellaterra (Spain).

Ginesta Rodriguez, MsC

Antonio David Dorado, PhD

Anna Bonsfills, $\mathrm{PhD}$

David Gabriel, PhD

Correspondence: Dr. Ing. X. Gamisans (xavierg@emrn.upc.edu), EPSEM, Universitat Politécnica de Catalunya (UPC). Bases de Manresa, 61-73, 08242-Manresa, Spain.
} 
1.Introduction

The recovery of energy-rich gases has grown in importance in recent years. European directive 1999/31/CE on landfill of waste stipulates that all landfill sites storing biodegradable waste must make provision for collecting and treating the biogas emitted for subsequent reuse as an energy source. Harnessing the biogas generated during anaerobic digestion processes at municipal landfills and wastewater treatment plants has therefore become a promising means of obtaining energy and reducing the emission of pollutant gases into the atmosphere. However, biogas contains hydrogen sulfide $\left(\mathrm{H}_{2} \mathrm{~S}\right)$ at concentrations of $1000-4000 \mathrm{ppm}_{\mathrm{v}}$ [1], which is sufficient to corrode processing equipment and, when released into the atmosphere, is an acid rain precursor. Cogeneration motors, used to generate electric and thermal energy, require $\mathrm{H}_{2} \mathrm{~S}$ concentrations of less than $500 \mathrm{ppm}_{\mathrm{v}}$. Biological techniques have proved to be an effective and environmentally friendly solution for removing large quantities of hydrogen sulfide and are less costly than physicochemical techniques [2].

The most common systems for biological removal of hydrogen sulfide are biotrickling filters and bioscrubbers [3]. A bioscrubber consists of two operational components: a gas-liquid column (where contaminant transfer occurs) and an aeration tank. Instead, in a biotrickling filter, the pollutant is absorbed and removed in a packed column, being the liquid phase continuously recirculated from the bottom of the reactor [4].

The biological oxidation of $\mathrm{H}_{2} \mathrm{~S}$ occurs in two stages according to reactions 1 and 2. In the first step the hydrogen sulfide is oxidized into elemental sulfur, in the second stage the elemental sulfur is oxidized into sulfate. $[5,6]$ :

$\mathrm{HS}^{-}+0.5 \mathrm{O}_{2}+\mathrm{H}^{+} \rightarrow \mathrm{S}^{0}+\mathrm{H}_{2} \mathrm{O}$

$\mathrm{S}^{0}+\mathrm{H}_{2} \mathrm{O}+1.5 \mathrm{O}_{2} \rightarrow \mathrm{SO}_{4}{ }^{2-}+2 \mathrm{H}^{+}$

When high concentrations of dissolved oxygen (DO) are present, hydrogen sulfide is oxidized to sulfate, which can be removed by purging the liquid phase. However, when DO levels are insufficient, microorganisms can only oxidize the $\mathrm{H}_{2} \mathrm{~S}$ to elemental sulfur an insoluble solid that builds up in the packing material of the biofilter, increasing pressure drop, raising pumping costs and potentially requiring equipment to be shut down so that the packing material can be cleaned or replaced [7]. In standard processes, the contribution of oxygen to the biological process is achieved by injecting air together with the biogas. In this type of aeration system, oxygen transfer occurs throughout the biofilter. Oxygen has a low solubility in water of $8.37 \mathrm{mg}$ $1^{-1}$ (air at $25{ }^{\circ} \mathrm{C}$ and $1 \mathrm{~atm}$ ) [8], meaning that oxygen limitation is a common problem when treating large amounts of hydrogen sulfide. As such, one possible strategy for obtaining the biological oxygen demand required to oxidize hydrogen sulfide to sulfate is to optimize the airto-water oxygen transfer. 
Despite its importance in the biological removal of $\mathrm{H}_{2} \mathrm{~S}$, optimization of oxygen transfer has received little attention in the literature. Despite its importance in the biological removal of $\mathrm{H}_{2} \mathrm{~S}$, optimization of oxygen transfer has received little attention in the literature. Alcantara et al. (2004) studied the relevance of dissolved oxygen in the liquid phase for a bioscrubber to remove hydrogen sulfide at different oxygen/sulfide ratios [9]. Authors observed that at flowrate ratios below 0.5 the hydrogen sulfide oxidation is incomplete producing mainly elemental sulfur. On the contrary, at flowrate ratios above 2 the oxidation is complete to sulfate. Similarly, Charnnok et al. (2012) underlined the importance of oxygen transfer to achieve high hydrogen sulfide removal in biogas sweetening at extreme acidic conditions [10]. In this study the use of membrane diffusers to transfer oxygen directly into the liquid phase is proposed. As described above, biological oxidation of hydrogen sulfide generates sulfate that accumulates in the liquid phase. It is therefore of interest to examine the effect of sulfate on oxygen transfer. In addition, the biogas is often stored above atmospheric pressure, so it is also important to determine the possible effect of the working pressure in the system.

Also the addition of a non-aqueous phase to optimize oxygen transfer in a bioscrubber system is proposed. The use of more than one phase has mainly been studied in two-phase partitioning bioreactors, where the presence of the non-aqueous phase has been found to increase the mass transfer rate [11]. Recently the use of solid inert polymers has been studied due their low cost, easy separation and recycling possibilities $[12,13]$.

According to the stated above, main parameters that affect the gas-liquid oxygen transfer by means of membrane diffusers were tested under common biofiltration conditions. In addition the improvements that can be achieved through direct injection of oxygen and the use of a nonliquid phase (NLP) as mass transfer vector were also studied.

\section{Materials and methods}

Oxygen transfer experiments were carried out using the equipment described in Rodriguez et al. (2012), which consists of a 2001 tank (114.4 cm height and $50 \mathrm{~cm}$ of inner diameter) and a 31 $\mathrm{cm}$ fine bubble diffuser (Roediger ROEFLEX, Sacede) mounted near the tank bottom [14]. The variables measured were the liquid phase DO concentration and temperature (CellOx 325 probe, WTW), the supplied air flowrate (PT-313-0400 variable area flowmeter, Tecfluid), the tank pressure (ZSE40/ISE40 high-precision digital pressure switch, SMC) and the sulfate concentration (ICS-1000 ion chromatography system, DIONEX).

Experiments were conducted at a constant temperature of $22 \pm 3{ }^{\circ} \mathrm{C}$ and at atmospheric pressure, except for those experiments in which the tank was pressurized, which were conducted at relative pressures in the range 0-0.5 bar. The reagents were nitrogen ( $99.99 \%$, Abelló Linde), oxygen (99.95\%, Abelló Linde) and sodium sulfate (99\%, Scharlab). The transfer vector used 
was Desmopan ${ }^{\circledR}($ DP9370A, $3 \times 3 \mathrm{~mm}$ cylinders, polyurethane of poly(oxytetramethylene)glycol and methyldiisocyanate, Bayer), as NLP.

For data acquisition a SCADA system in LabWindows ${ }^{\mathrm{TM}}$ was used. The DO sensor was connected to an inoLab740 meter (WTW) linked to the computer via a RS-232 interface.

The mass transfer coefficient was calculated from a mass balance model according to the standardized ASCE/EWRI 2-06 equation, 2007 [15], under dynamic conditions:

$\frac{d C_{L}}{d t}=K_{L} a \cdot\left(C_{S}-C_{L}\right)$

Equation (3) was solved by the fminsearch algorithm in Matlab using the Simplex search method at initial conditions $\mathrm{t}=0$ and $\mathrm{C}_{\mathrm{L}}=\mathrm{C}_{\mathrm{L}}(0)$.

The mass transfer coefficient values obtained give a reference temperature of $20{ }^{\circ} \mathrm{C}$, which can be corrected using Equation (4):

$$
K_{L} a_{20}=K_{L} a \cdot \Theta^{(20-T)}
$$

The amount of oxygen transferred to the liquid phase was determined using Equation (5), where SOTR is the standard oxygen transfer rate, expressed in $\mathrm{Kg} \mathrm{O}_{2} \mathrm{~h}^{-1}$ :

$S O T R=K_{L} a_{20} \cdot C_{S} \cdot V_{T}$

Before each experiment, the liquid phase was deoxygenated with nitrogen to a concentration of $2-3 \mathrm{mg} \mathrm{l}^{-1} \mathrm{DO}$. The coefficient measurement error was $10 \%$, below the maximum allowed error of 15\% established in ASCE/EWRI 2-06 [15].

As stated in the literature, sensor response times below $1 / \mathrm{K}_{\mathrm{L}} \mathrm{a}$ can be disregarded when calculating the mass transfer coefficient [16]. Here, the sensor response time was determined using the method proposed by Vandu et al. (2004) [17], and a value of less than $1 / \mathrm{K}_{\mathrm{L}} \mathrm{a}$ was obtained.

\section{Results and discussion}

\subsection{Effect of air flowrate}

Taking as a reference the biofilter described by Tomàs et al. (2009) [18], the stoichiometric oxygen requirement for treating up to $1500 \mathrm{ppm}_{\mathrm{v}}$ of $\mathrm{H}_{2} \mathrm{~S}$ with a biogas flowrate of $40 \mathrm{~m}^{3} \mathrm{~h}^{-1}$ will be in the range $1-7 \mathrm{~m}^{3} \mathrm{~h}^{-1}$ of air $\left(0.3-2.1 \mathrm{~kg} \mathrm{O}_{2} \mathrm{~h}^{-1}\right)$. Consequently, experiments were conducted with supplied air flowrates from the diffuser in the range $1.2-6.7 \mathrm{~m}^{3} \mathrm{~h}^{-1}$ at atmospheric pressure. Figure 1 shows the air flowrates in the range $2.3-6.7 \mathrm{~m}^{3} \mathrm{~h}^{-1}$, a linear relationship is observed between SOTR and the gas flowrate; when the air supply is increased, the oxygen transfer rates rises. These results are consistent with those obtained by Cachaza et al. (2008) [19] in a bubble column reactor, using a perforated plate to introduce air into the system.

Doubling the air flow from 1.2 to $2.34 \mathrm{~m}^{3} \mathrm{~h}^{-1}$ increased oxygen transfer by $59 \%$ (which graphically corresponds to a value of $0.026 \mathrm{~kg} \mathrm{O}_{2} \mathrm{~m}_{\text {air }}^{-3}$ ). When the supplied air flowrate is 
increased until $6.7 \mathrm{~m}^{3} \mathrm{~h}^{-1}$, the oxygen transfer further improved by up to $118 \%\left(0.021 \mathrm{~kg} \mathrm{O}_{2} \mathrm{~m}_{\text {air }}{ }^{-}\right.$

$\left.{ }^{3}\right)$. These results clearly indicate that the supplied air flowrate has a strong effect on the amount of oxygen transferred.

\subsection{Addition of pure oxygen}

Figure 2 shows the SOTR obtained in experiments with addition of oxygen according to the supplied oxygen flowrate. Flows in the range $0.24-0.48 \mathrm{~m}^{3} \mathrm{~h}^{-1}$ were used, which supply an equivalent volume of oxygen to air flowrates of $1.2-2.4 \mathrm{~m}^{3} \mathrm{~h}^{-1}$. As can be seen in Figure 2, lower oxygen transfer rates are achieved when pure oxygen is added to the system. If the same volumetric flowrates were used for pure oxygen and air, rather than an equivalent oxygen flowrate, oxygen transferred would be higher with the addition of pure oxygen. Using an equivalent oxygen flowrate ensures that the hydrodynamic conditions are comparable (same mass transfer coefficient) but the mass transferred is enhanced due to a higher driving force for oxygen pure in comparison to air.

At oxygen flowrates of $0.24-0.48 \mathrm{~m}^{3} \mathrm{~h}^{-1}$, the total gas-liquid contact area is considerably smaller than that at the equivalent air flowrates (considering the bubbles size is kept constant at the flowrates range tested) and, what it is more important, the decrease of the turbulence at lower flowrates decrease significantly the oxygen transfer rate. In addition, when working with pure oxygen, the partial pressure of oxygen in the gas phase increases, raising the driving force of oxygen transfer. However, as can be seen in Figure 2, when pure oxygen is added at an equivalent oxygen flowrate to that achieved by the addition of air, the resulting oxygen transfer rate is higher. This is corroborated by discontinuous stirred-tank reactor experiments carried out by Pinelli et al. (2010) [20], who noted that the increase in $\mathrm{k}_{\mathrm{L}}$ does not compensate for the reduction of the specific area, relating it to a decrease in gas hold-up. In addition, it is important to note that oxygen addition requires less energy consumption than the addition of air: the values of oxygen transfer as a function of energy supplied (measured as standard aeration efficiency, SAE, in $\mathrm{kg} \mathrm{O}_{2} \mathrm{~h}^{-1} \mathrm{~kW}^{-1}$ ) are 0.62 and $3.31 \mathrm{~kg} \mathrm{O}_{2} \mathrm{~h}^{-1} \mathrm{~kW}^{-1}$ for the addition of air and pure oxygen, respectively. However, the oxygen production entails an additional cost not accounted when air is used.

\subsection{Effect of pressure}

Figure 3 shows the oxygen transfer rate at relative pressures inside the tank in the range $0-0.5$ barg, with an air flowrate of $1.2 \mathrm{~m}^{3} \mathrm{~h}^{-1}$ supplied by the diffuser. The pressure range used in these experiments reproduces the working pressure conditions of the biogas storage system for the Manresa and St. Joan de Vilatorrada (Barcelona, Spain) wastewater treatment plant [18]. Contrary to the expected outcome, the oxygen transfer rate showed a slight decreasing trend as the relative pressure in the system increased (a total decrease in oxygen transfer of $8.3 \%$ was observed over the relative pressure range studied). However, considering the error associated 
with SOTR measurements is $10 \%$, and according to an ANOVA statistical test performed, this differences were not statistically different at $5 \%$ level of significance.

Bubble diameter should be smaller at higher working pressures. Smaller bubbles provide a larger total mass transfer area, meaning that the transfer rate should be higher in pressurized systems. Experiments were conducted to dismiss possible DO sensor errors caused by the increase in working pressure in the system (data not shown).

The literature is inconclusive regarding the effect of pressure increase on mass transfer coefficients. Han and Al-Dahhan (2007) [21] found that $\mathrm{k}_{\mathrm{L}}$ remained constant or decreased slightly at higher pressures because the liquid properties varied only slightly in the pressure range tested (1.4-10.0 barg). Letzel and Stankiewicz (1999) [22], who used a pressure range of 1-13 barg in a bubble column, observed that $\mathrm{k}_{\mathrm{L}} \mathrm{a}$ increased with pressure. This outcome was explained by the fact that the higher pressure increases the gas density, reducing the stability of the bubbles and lowering the coalescence rate. By contrast, Yoshida and Arakawa (1968) [23] found that $\mathrm{k}_{\mathrm{L}}$ a decreased at higher pressures, particularly with a low agitation rate, which was related to the surface renewal rate or degree of interfacial turbulence, arguing that the increase in pressure changes the surface tension and causes the gas-liquid interface to become rigid. The results presented in this study are in agreement with those reported by Heijnen et al. (1980) and Masutani and Stenstrom (1991) [24, 25].

\subsection{Effect of sulfate concentration}

Figure 4 shows the evolution of oxygen transfer at sulfate concentrations in the aqueous phase from 0 to $1000 \mathrm{mg} \mathrm{l}^{-1}$. The chosen range of concentrations was designed to ensure that bacterial activity is not inhibited, an effect that is observed at a sulfate concentration of $1900 \mathrm{mg} \mathrm{l}^{-1}$, according to Jin et al. (2005) [26] and $5000 \mathrm{mg} \mathrm{l}^{-1}$ according to Ramirez et al. (2009) [27]. Experiments were conducted with air flowrates of 1.2, 1.8 and $2.4 \mathrm{~m}^{3} \mathrm{~h}^{-1}$. Oxygen transfer increased with sulfate concentration in the aqueous phase, with a total increase in SOTR of $34 \%$ over the concentration range $0-1000 \mathrm{mg} \mathrm{l}^{-1}$.

Similarly, Jamnongwong et al. (2010) [28] studied the effect of salt content on mass transfer coefficients in a bubble column reactor equipped with a membrane diffuser. They concluded that the addition of salt increases the surface tension of the water-a phenomenon known as the Marangoni effect - to generate greater interfacial turbulence, raising the interface renewal rate and leading to increased oxygen transfer. Bubble column experiments conducted by Painmanakul and Hebrard (2008) [29] showed that higher salt concentrations reduce bubble coalescence, thereby increasing the mass transfer area and leading to a higher rate of oxygen transfer. 


\subsection{Effect of non-liquid phase addition}

In biofiltration systems containing poorly water soluble compounds, if an immiscible second phase is added, the total oxygen transfer from the gas phase to the aqueous phase is the sum of the oxygen transferred from the gas to the non-aqueous phase and the oxygen transferred from the non-aqueous to the aqueous phase [30]. According to Muñoz et al. (2007) [31], the overall mass transfer in multiphase systems is controlled by transfer from the gas to the non-aqueous phase.

Figure 5 shows the oxygen transfer rate at air flows of 3.0, 4.2 and $6.6 \mathrm{~m}^{3} \mathrm{~h}^{-1}$ with NLP concentrations of $0,1,3,5,7$ and $9 \% \mathrm{v} / \mathrm{v}$. The oxygen transfer rate increased with NLP concentration at all three of the air flowrates tested, up to a concentration of $3 \% \mathrm{v} / \mathrm{v}$. These results are consistent with those obtained by Quijano et al. (2010a) and (2010b) [32, 33], who experimented with the use of multiphase systems for removal of ethanol and toluene, respectively. However, when the NLP concentration was increased to above $3 \% \mathrm{v} / \mathrm{v}$, oxygen transfer fell at the 3.0 and $4.2 \mathrm{~m}^{3} \mathrm{~h}^{-1}$ air flowrates. This abrupt drop in oxygen transfer at higher second-phase concentrations was also witnessed by Quijano et al. (2009) [34], who used silicone oil as a mass transfer vector at concentrations of $0-50 \% \mathrm{v} / \mathrm{v}$. At silicone oil concentrations above $10 \%$, the global mass transfer coefficient decreased.

In their study with bubble column using hollow glass spheres as NLP, Mena et al. (2011) observed a mass transfer increase until $2-3 \% \mathrm{v} / \mathrm{v}$ de NLP. For expandable polystyrene the results are quite different; in this case the mass transfer decreases with the addition of the nonliquid phase. In agreement with the results obtained in this study, the experiments of Albal et al. (1983) showed that for solid particles concentration less than $5 \% \mathrm{v} / \mathrm{v}$ the mass transfer increased and for concentrations higher than 5\% the mass transfer decreased [36].

The reduction in mass transfer may be related to an increase in the apparent viscosity, since at higher viscosities the liquid turbulence decreases, leading to lower mass transfer rates [37].

At the highest air flowrate, oxygen transfer increased up to a NLP concentration of $5 \% \mathrm{v} / \mathrm{v}$, which indicates that the optimal proportion depends on the air flowrate supplied, since increasing the air flowrate increases the liquid phase turbulence. The addition of a non-aqueous phase at a concentration of $3 \% \mathrm{v} / \mathrm{v}$ led to an average increase in oxygen transfer of $32 \%$.

\section{Conclusions}

The experiments described above show that the typical working conditions of a biological desulfurization process are compatible with the addition of a fine bubble membrane diffuser and can in fact contribute to improving oxygen transfer rates. It was found that when pure oxygen is added instead of the equivalent oxygen volume in air, the rate of mass transfer is lowered due to the smaller available mass transfer area. Increasing the working pressure from 0 to 0.5 barg does not have a significant effect on oxygen transfer, but a $34 \%$ improvement in SOTR is observed 
when sulfate concentration is increased from 0 to $1000 \mathrm{mg} \mathrm{l}^{-1}$. The addition of a $3 \% \mathrm{v} / \mathrm{v}$ nonaqueous phase increased oxygen transfer by an average of $32 \%$. The addition of a transfer vector is a possible means of improving oxygen transfer, up to a certain concentration of the non-aqueous phase. This study demonstrates that oxygen transfer is largely insensitive to working pressure but responds strongly to the supplied air flowrate.

\section{Acknowledgements}

Authors acknowledge the financial support provided by the "Comision Interministerial de Ciencia y Tecnologia" (CICYT) and the European Regional Development Fund (ERDF-EC), project CTQ 2009-14338-C03-03.

\section{Nomenclature}

$\mathrm{a}=$ Specific contact area, $\mathrm{m}^{2} \mathrm{~m}^{-3}$

$\mathrm{C}_{\mathrm{L}}=$ Dissolved oxygen concentration at the liquid phase, $\mathrm{kg} \mathrm{m}^{-3}$

$\mathrm{C}_{\mathrm{S}}=$ Dissolved oxygen concentration at saturation, $\mathrm{kg} \mathrm{m}^{-3}$

$\mathrm{DO}=$ Dissolved oxygen

$\mathrm{K}_{\mathrm{L}}=$ Global mass transfer coefficient, $\mathrm{s}^{-1}$

$\mathrm{k}_{\mathrm{L}}=$ Liquid side mass transfer coefficient, $\mathrm{m} \mathrm{s}^{-1}$

$\mathrm{K}_{\mathrm{L}} \mathrm{a}_{20}=$ Volumetric mass transfer coefficient corrected at $20{ }^{0} \mathrm{C}$ and pressure of $1 \mathrm{~atm}, \mathrm{~s}^{-1}$

NLP $=$ Non-liquid phase

$\mathrm{Q}_{\mathrm{G}}=$ Gas flowrate, $\mathrm{m}^{3} \mathrm{~s}^{-1}$

$\mathrm{SAE}=$ Standard Aeration Efficiency, $\mathrm{kg} \mathrm{O}_{2} \mathrm{~kW}^{-1} \mathrm{~h}^{-1}$

SOTR $=$ Standard Oxygen Transfer Rate, $\mathrm{kg} \mathrm{O}_{2} \mathrm{~h}^{-1}$

$\mathrm{t}=$ experimental time, $\mathrm{s}$

$\mathrm{T}=$ Temperature, ${ }^{0} \mathrm{C}$

$\mathrm{V}_{\mathrm{T}}=$ Volume of the tank, $\mathrm{m}^{3}$

$\Theta=$ empirical temperature correction factor, 1.024, dimensionless

$\mathrm{H}=$ Henry coefficient, dimensionless

\section{References}

[1] J. Walsh, C. Ross, M. Smith, S. Harper and W. Wilkins, Handbook of biogas utilization, 1st ed., The Environment, Health and Safety Divsion, Georgia 1998.

[2] S. Kim and M. A. Deshusses, Chem. Eng. J. 2005, 113, 119-126. DOI: 10.1016/jcej.200505001.

[3] M. Syed, G. Soreanu, P. Faetta and M. Béand, Canadian Biosystems Engineering 2006, $48,2.1-2.14$. 
[4] C. Kennes and M. C. Veiga, Bioreactors for waste gas treatment, 1st ed., Klewer Academic Publishers, Dordrecht 2001.

[5] M. T. Madigan, J. M. Martinko and J. Parker, Brock Biology of microorganisms, 12th ed., San Francisco 2009.

[6] J.G. Kuenen, Plant Soil 1975, 43, 49-76. DOI: 10.1007/BF01928476

[7] M. Fortuny, J. A. Baeza, X. Gamisans, C. Casas, J. Lafuente, M. A. Deshusses and D. Gabriel, Chemosphere 2008, 71, 10-17. DOI: 10.1016/jchemosphere.200710072.

[8] R. H. Perry and D. W. Green, Perry's Chemical Engineers' Handbook, 7th ed., McGraw-Hill, USA 1997.

[9] S. Alcantara, A. Velasco, A. Munoz, J.Cid, S. Revah and E. Razo-Flores, Environ. Sci. Technol. 2004, 38, 918-923. DOI: 10.1021/es034527y

[10] B. Charnnok, T. Suksaroj, P. Boonswang and S. Chaiprapat, Bioresource Technol. 2012, in press. DOI:10.1016/j.biortech.2012.12.114

[11] E. Dumont, G. Darracq, A. Couvert, C. Couriol, A. Amrane, D. Thomas, Y. Andrès and P. Le Cloirec, Chem. Eng. Sci. 2012, 71, 146-152. DOI: 10.1016/jces.201112017.

[12] J. Rocha-Rios, G. Quijano, F. Thalasso, S. Revah and R. Munoz, J. Chem. Techn. Biot. 2011, 86, 353-360. DOI: 10.1002/jctb.2523

[13] R. Muñoz, A. J. Daugulis, M. Hernández and G. Quijano, Biotechnol. Adv. 2012, 30, 410-422. DOI: 10.1016/j.biotechadv.2012.08.009

[14] G. Rodriguez, A. D. Dorado, A. Bonsfills, R. Sanahuja, D. Gabriel and X. Gamisans, J. Chem. Technol. Biot. 2012, 87, 854-860. DOI: 10.1002/jctb.3731.

[15] ASCE, Measurement of oxygen transfer in clean water ASCE standard, ASCE/EWRI 206. American Society of Civil Engineers, Reston 2007.

[16] K. Van't Riet, Ind. Eng. Chem. Proc. Des. Dev. 1979, 18, 357-364. DOI: 10.1021/i260071a001.

[17] C. O. Vandu, K. Koop and R. Krishna, Chem. Eng. Sci. 2004, 59, 5417-5423. DOI: 10.1016/jces.200407085.

[18] M. Tomàs, M. Fortuny, C. Lao, D. Gabriel, J. Lafuente and X. Gamisans, Water Practice and Technology 2009, 4, 26-33. DOI: 10.2166/wpt.2009026.

[19] E. M. Cachaza, M. E. Diaz, F. J. Montes and M. A. Galan, Ind. Eng. Chem. Res. 2008, 47, 4510-4522. DOI: 10.1021/ie800135h.

[20] D. Pinelli, Z. H. Liu and F. Magelli, Int. J. Chem. Reac. Eng. 2010, 8 (1), 40. DOI: $10.2202 / 1542-65801915$.

[21] L. Han and M. H. Al-Dahhan, Chem. Eng. Sci. 2007, 62, 131-139. DOI: 10.1016/jces.200608010.

[22] M. Letzel and A. Stankiewicz, Chem. Eng. Sci. 1999, 54, 5153-5157. DOI: 10.1016/s00092509. 
[23] F. Yoshida and S. I. Arakawa, Aiche J. 1968, 14, 962-963. DOI: 10.1002/aic.690140624.

[24] J. J. Heijnen, K. V. Riet and A. J. Wolthuis, Biotechnol. Bioeng. 1980, 22, 1945-1956. DOI: 10.1002/bit.260220912.

[25] G. K. Masutani and M. K. Stenstrom, J. Environ. Eng-Asce 1991, 117, 126-142. DOI: 10.1061/asce07339372.

[26] Y. M. Jin, M. C. Veiga and C. Kennes, J. Chem. Technol. Biot. 2005, 80, 998-1004. DOI: $10.1002 /$ jctb. 1275 .

[27] M. Ramirez, J. Manuel Gomez, G. Aroca and D. Cantero, Bioresource Technol. 2009, 100, 4989-4995. DOI: 10.1016/j.biortech.2009.05.022

[28] M. Jamnongwong, K. Loubiere, N. Dietrich and G. Hebrard, Chem. Eng. J. 2010, 165, 758-768. DOI: $10.1016 /$ jcej.201009040.

[29] P. Painmanakul and G. Hebrard, Chem. Eng. Res. Des. 2008, 86, 1207-1215. DOI: 10.1016/jcherd.200806009.

[30] A. J. Daugulis, B. G. Amsden, J. Bochanysz and A. Kayssi, Biotechnol. Lett. 2003, 25, 1203-1207. DOI: 10.1023/a:1024593231015.

[31] R. Muñoz, S. Villaverde, B. Guieysse and S. Revah, Biotechnol. Adv. 2007, 25, 410422. DOI: 10.1016/jbiotechadv200703005.

[32] G. Quijano, M. Hernandez, S. Villaverde, F. Thalasso and R. Muñoz, Appl. Microbiol. Biot. 2010, 85, 543-551. DOI: 10.1007/s00253-009-2146-x

[33] G. Quijano, J. Rocha-Rios, M. Hernandez, S. Villaverde, S. Revah, R. Munoz and F. Thalasso, J. Hazard. Mater. 2010, 175, 1085-1089. DOI: 10.1016/j.jhazmat.200910020.

[34] G. Quijano, S. Revah, M. Gutierrez-Rojas, L. B. Flores-Cotera and F. Thalasso, Process Biochem. 2009, 44, 619-624. DOI: 10.1016/jprocbio.200901015.

[35] R.S. Albal, Y. T. Shah, A. Schumpe and N. L. Carr, Chem. Eng. J. 1983, 27, 61-80. DOI: 10.1016/0300-9467(83)80053-7

[36] P. Mena, A. Ferreira, J. A. Teixeira and F. Rocha, Chem. Eng. and Processi.: Process Intensification 2011, 50, 181-188. DOI: 10.1016/j.cep.2010.12.013

[37] J. H. Lee and N. R. Foster, App. Catal. B-Environ. 1990, 63, 1-36. DOI: 10.1016/S01669834. 
Figure 1: SOTR with air flowrates in the range $1.4-6.7 \mathrm{~m}^{3} \mathrm{~h}^{-1}$.

Figure 2: SOTR and flowrate for the addition of pure oxygen $\left(\mathrm{Q}_{\mathrm{O} 2}\right)$ and equivalent air $\left(\mathrm{Q}_{\mathrm{Air}}\right)$.

Figure 3: SOTR and relative pressure inside the tank for an air flowrate of $1.2 \mathrm{~m}^{3} \mathrm{~h}^{-1}$

Figure 4: SOTR and sulfate concentration in the aqueous phase for air flows of 1.2, 1.8 and 2.4 $\mathrm{m}^{3} \mathrm{~h}^{-1}$

Figure 5: SOTR and NLP concentration, for air flowrates of 3.0, 4.2 and $6.6 \mathrm{~m}^{3} \mathrm{~h}^{-1}$. 


\section{Text for the Table of Contents}

The effect of different operating variables on the oxygen mass transfer process has been tested in a pilot plant using a membrane diffuser as intensive gas-liquid contactor. Tests performed simulated those conditions found in the biofiltration of $\mathrm{H}_{2} \mathrm{~S}$ at high loads for biogas sweetening. Results showed interesting effects on the mass transfer process when increasing the solution ions concentration and with the addition of a non-liquid phase (NLP). 


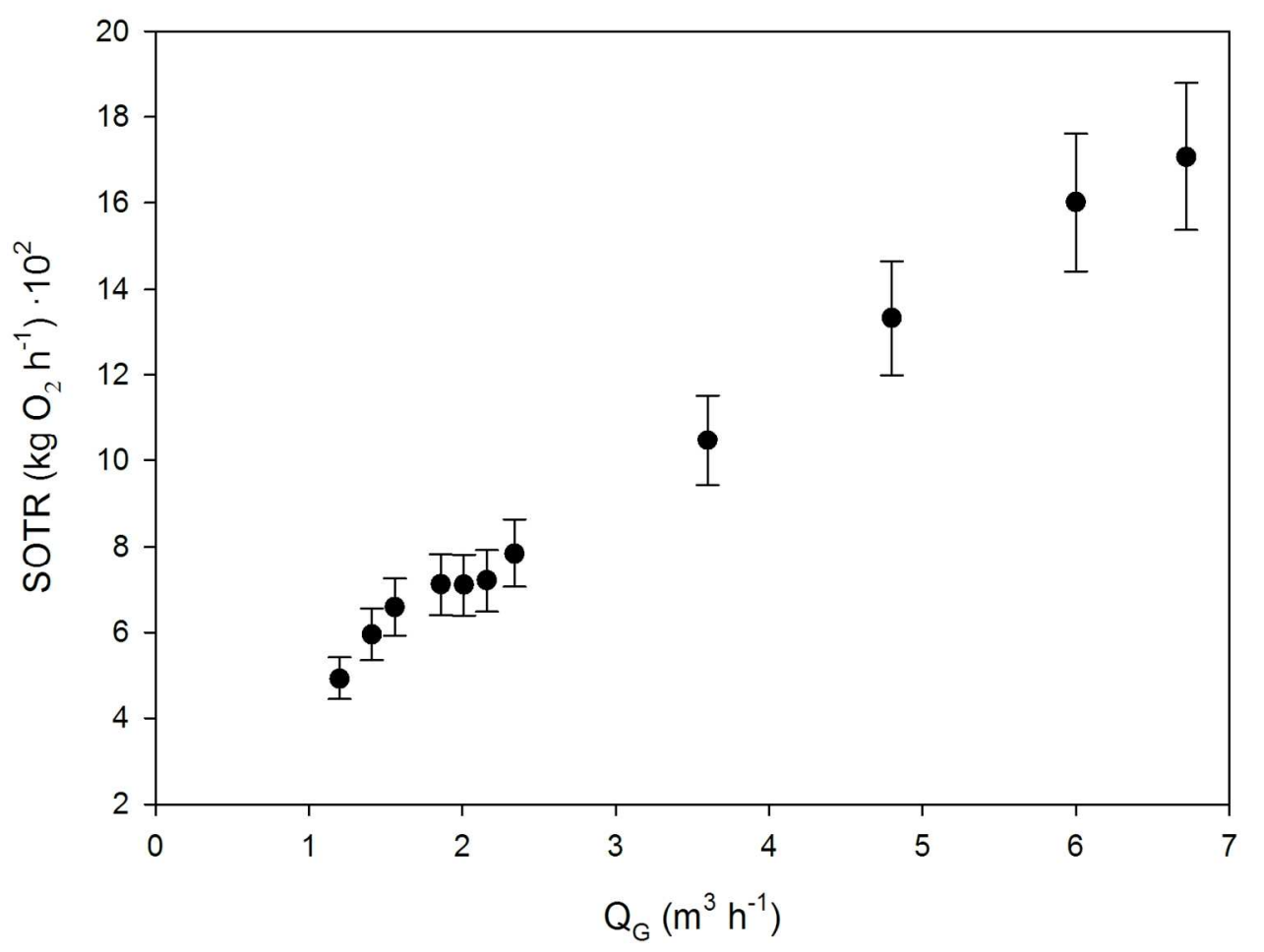

$148 \times 120 \mathrm{~mm}(300 \times 300$ DPI $)$ 


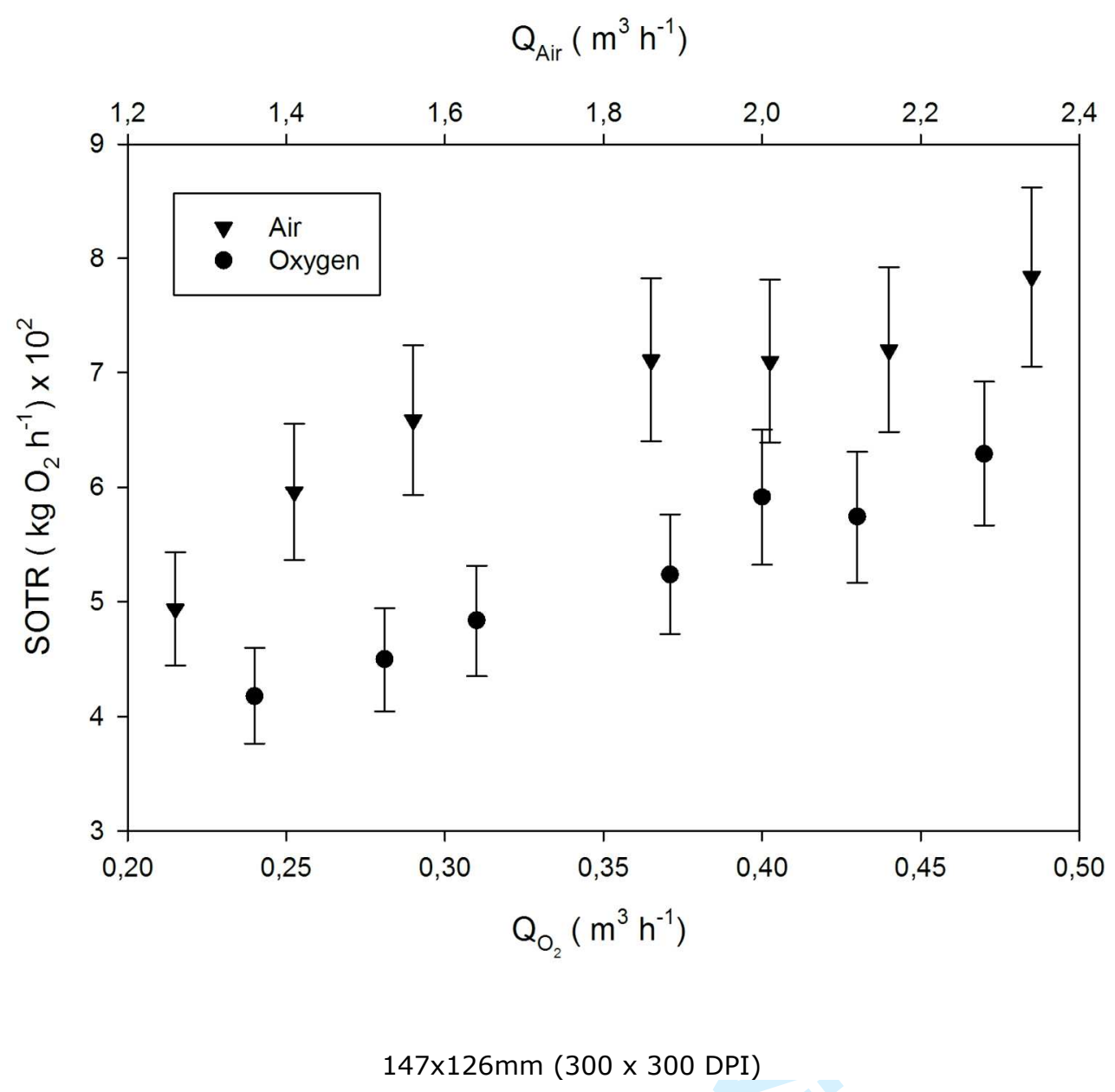

Wiley-VCH 


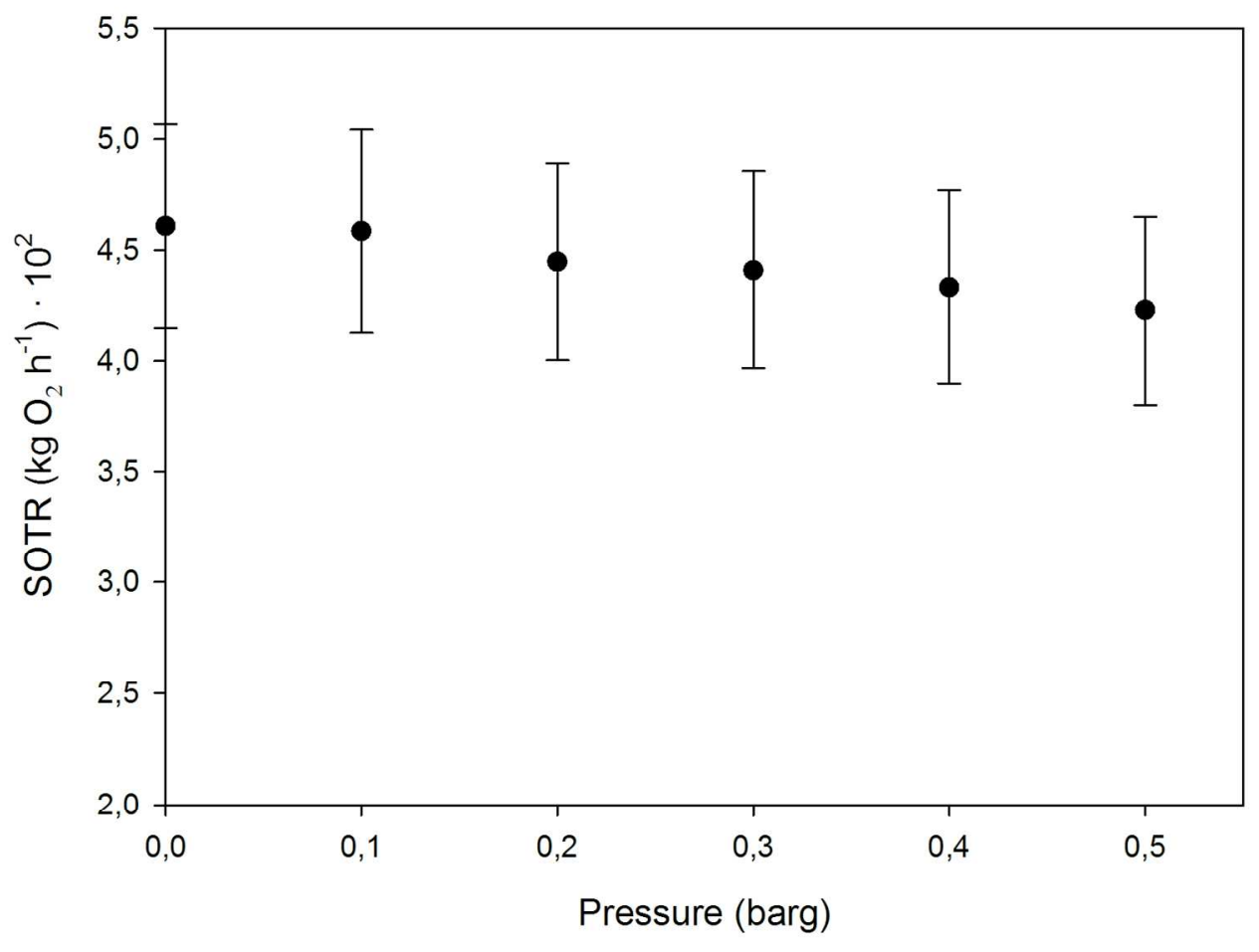

$149 \times 118 \mathrm{~mm}(300 \times 300$ DPI $)$ 


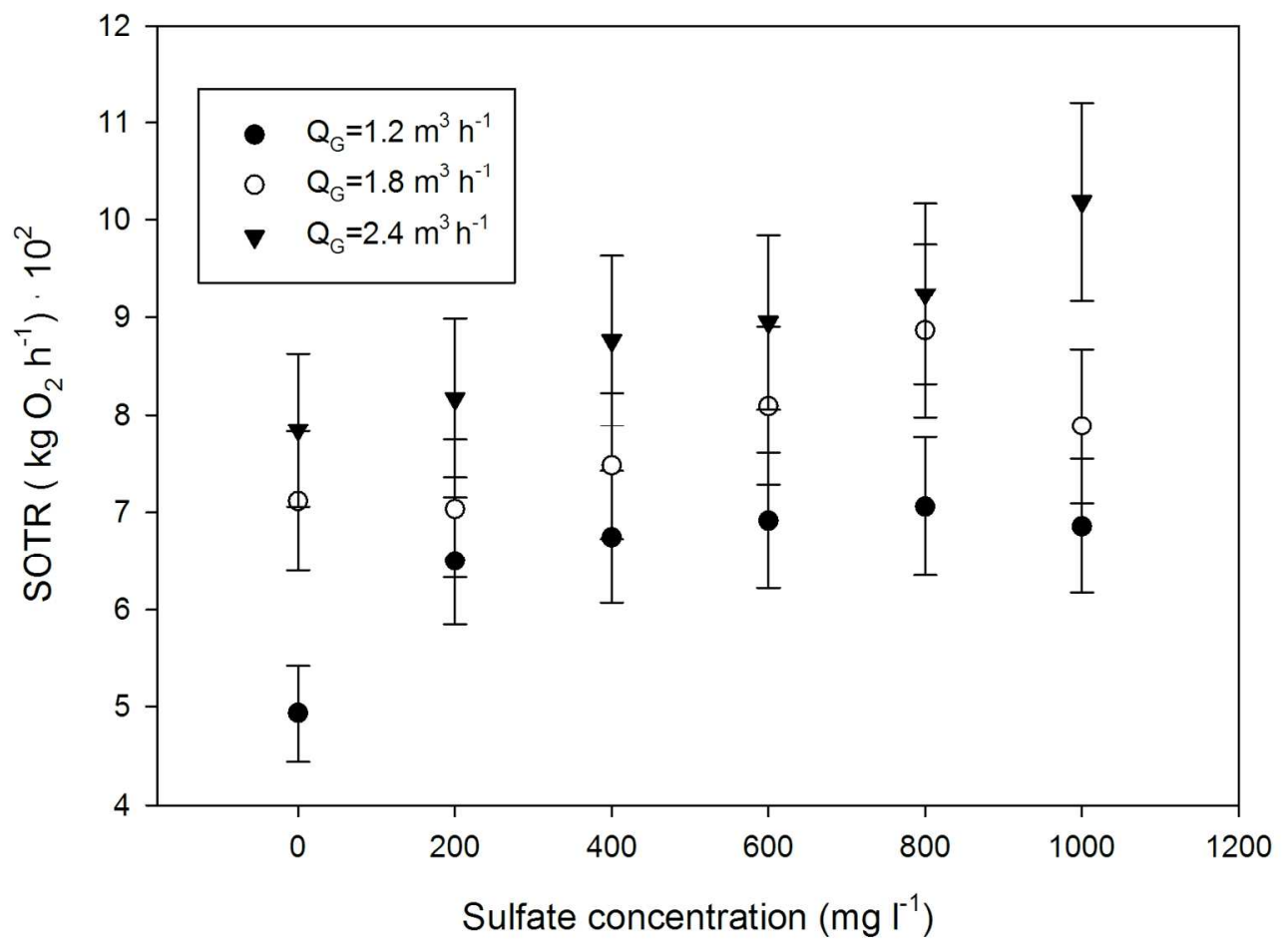

$149 \times 119 \mathrm{~mm}(300 \times 300$ DPI $)$ 


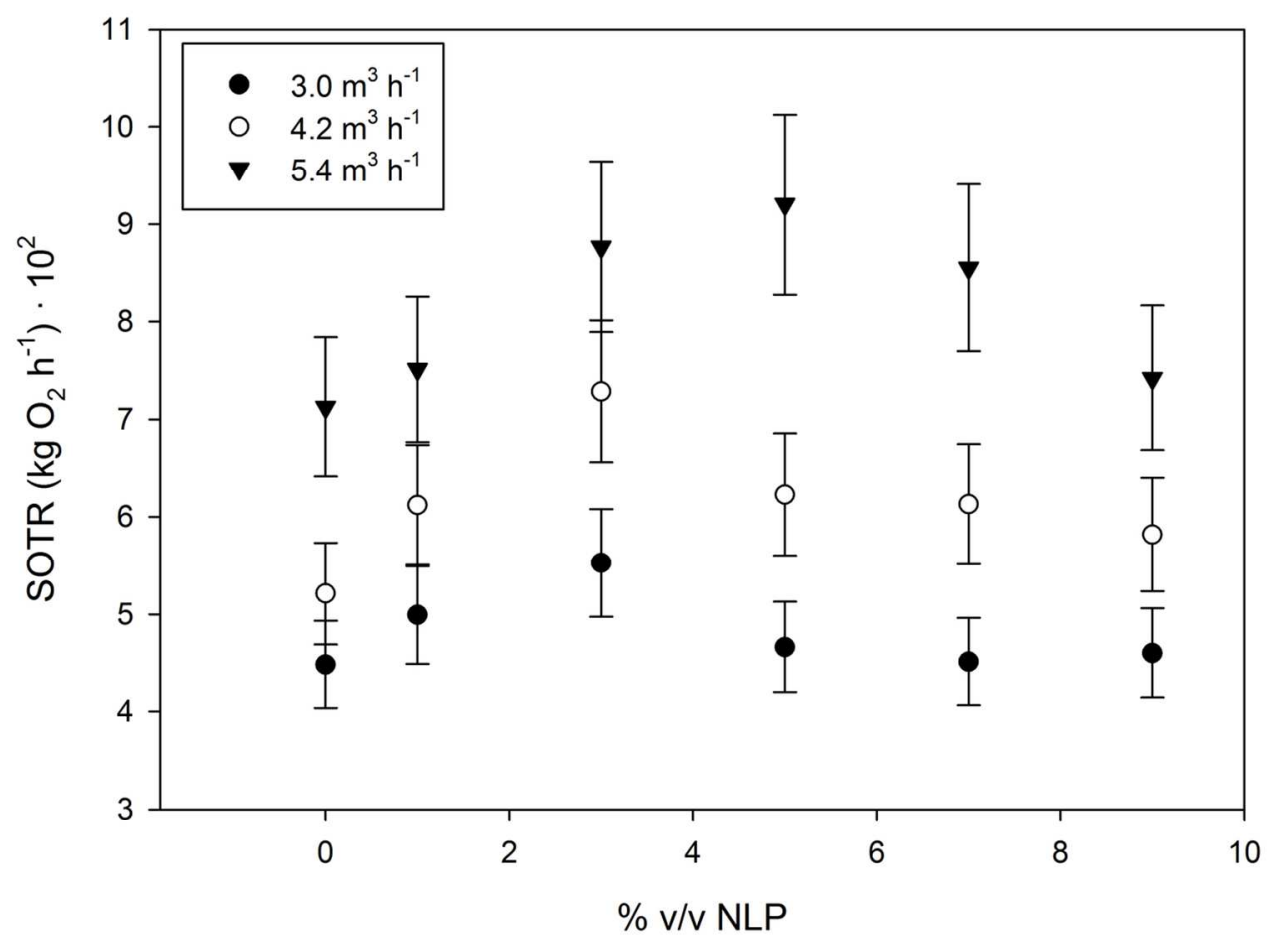

Figure 5 $119 \times 95 \mathrm{~mm}(300 \times 300$ DPI $)$ 